\title{
Policy Uncertainty and the Demand for Money in Japan
}

\author{
MOHSEN BAHMANI-OSKOOEE * \\ University of Wisconsin-Milwaukee
}

\author{
MAJID MAKI NAYERI \\ University of Wisconsin-Milwaukee
}

\begin{abstract}
In an attempt to establish stability of the demand for money, some recent studies have included the volatility of the money supply and output to account for uncertainty. In this paper we consider the experience of Japan but rather than including an uncertainty measure related to money supply and output, we include a relatively more comprehensive measure known as Economic Policy Uncertainty. When we included this later measure, we were unable to find a stable money demand in Japan. However, when we introduced the nonlinear adjustment of policy uncertainty, we not only found a stable money demand but also meaningful estimates. Since the approach allows us to assess asymmetries, we found that in Japan the public hold more cash when there is an increase or a decrease in uncertainty.
\end{abstract}

Keywords: Money Demand, Japan, Policy Uncertainty, Asymmetry, Nonlinear ARDL

JEL Classifications: E41

\section{Introduction}

One of the macro topics that has received the greatest attention in the literature is the demand for money. Indeed, it has received so much attention that each advanced country has its own literature and our country of concern, Japan, is no exception. Most studies have been concerned with two issues, i.e., income elasticity and stability. The income elasticity basically tells us at what rate money supply should grow to support economic growth with no inflation. If such a policy is to be effective, money demand must be stable.

As far as the Japanese demand for money is concerned, findings are mixed at best. For example, while Fair (1987) found that income elasticity is zero, Bahmani-Oskooee and Pourheydarian (1990) reported an income elasticity of 0.62 . However, since both studies failed to account for integrating properties of the variables in their specifications, their estimates could

\footnotetext{
* The Center for Research on International Economics and Department of Economics The University of Wisconsin-Milwaukee, Milwaukee, WI 53201, bahmani@uwm.edu

(C) 2020 Mohsen Bahmani-Oskooee and Majid Maki Nayeri. Licensed under the Creative Commons Attribution - Noncommercial 3.0 Licence (http://creativecommons.org/licenses/bync/3.0/. Available at http: //rofea.org.
} 
be spurious. To avoid the spurious regression problem, Hoffman et al. (1995) employed Johansen's cointegration technique to show that variables in their specification of M1 money demand are cointegrated and M1 money demand is stable. Depending on the sample period and estimation method, they reported income elasticity that ranged from a minimum of -0.67 to a maximum of 1.22. However, when the M1 measure of the money supply was replaced by M2, Miyao (1996) who also used Johansen's cointegration method concluded that "the test results convey a strong impression that M2 demand cointegration does not exist in postwar Japan".

Failure to find cointegration and a stable M2 money demand by Miyao (1996) could be due to omitted variables. One variable that has entered into the money demand specification is the exchange rate, which is said to account for currency substitution. Thus, when BahmaniOskooee and Shabsigh (1996) included the nominal effective exchange rate of the yen in their specification, they showed that M2 is cointegrated with income, interest rate, and nominal effective exchange rate. The income elasticity was found to be 1.02, supporting the monetarist view that the money supply should grow at the rate that the Japanese economy grows. Similar results were also reported by Bahmani-Oskooee (2001) who applied Pesaran et al.'s (2001) ARDL bounds testing method under which variables could be integrated of order zero or one. After all, in many instances interest rate seems to be stationary while income or exchange rate is not.

Another missing variable that is said to contribute to the instability of money demand is the volatility of the money supply. The idea goes back to Friedman (1984) who argued that the volatility of the money supply as a measure of uncertainty can contribute to the volatility of the velocity of money, hence the instability of the money demand function. Choi and Oh (2003) then introduced a model which showed if monetary uncertainty affects the demand for money, so does output uncertainty. Either the measure of uncertainty induces people to keep more or less cash, depending upon their expectation of future employment. Studies that have tested the impact of these two uncertainty measures include Bruggemann and Nautz (1997) for Germany, Hall and Noble (1987) and Choi and Oh (2003) for the U.S., Bahmani-Oskooee and Xi (2011) for Australia, Bahmani-Oskooee et al. (2012) for China, Bahmani-Oskooee et al. (2013) for the emerging countries of Armenia, Bulgaria, the Czech Republic, Hungary, Poland, Russia, Bolivia, South Africa, Colombia, and Malaysia, Bahmani-Oskooee and Xi (2014) for India, Indonesia, Malaysia, Pakistan, the Philippines, and Singapore, Bahmani-Oskooee and Baek (2017) for Korea. Most of these studies do have a common feature in that they find that the effects of either uncertainty measure is temporary. No study has considered the experience of Japan.

Therefore, our main goal here is to reconsider the demand for money in Japan. We deviate from the previous research in two ways. First, rather than including a measure of monetary

\footnotetext{
${ }^{1}$ See Miyao (1996, p. 177).
} 
uncertainty and a measure of output uncertainty, we include in our specification a relatively more comprehensive measure of uncertainty, known as economic policy uncertainty. Clearly, uncertainty in a country is not just due to monetary or output volatility. Many other factors such as change in the tax system, change in government, terrorism, etc. can contribute to an uncertain environment. Today, the Economic Uncertainty Group that relies on Baker et al. (2016) constructs an uncertainty measure for several countries, including Japan. The measure is known as Policy Uncertainty (PU) and the group searches popular newspapers in a given country for such terms as "policy", "tax", "spending", "regulation", "central bank", "budget", "uncertain", "uncertainty", "deficit", etc. Since different newspapers may discuss different aspects of uncertainty associated with each term, the higher the collected numbers, the higher the uncertainty, after being normalized. ${ }^{2}$ In order to gain some insight into the performance of this measure in Japan, we plot it in Figure 1.

The second point upon which we deviate from previous research is incorporating the nonlinear adjustment of policy uncertainty. There is now clear evidence that failure to find a significant relation between two variables could be due to assuming a linear relationship. Incorporating nonlinear adjustment of policy uncertainty amounts to assessing the possibility of an asymmetric response of the public's cash holding to changes in the policy uncertainty measure. Do Japanese respond to an increase in uncertainty differently than they do to a

Figure 1: A Measure of Policy Uncertainty for Japan

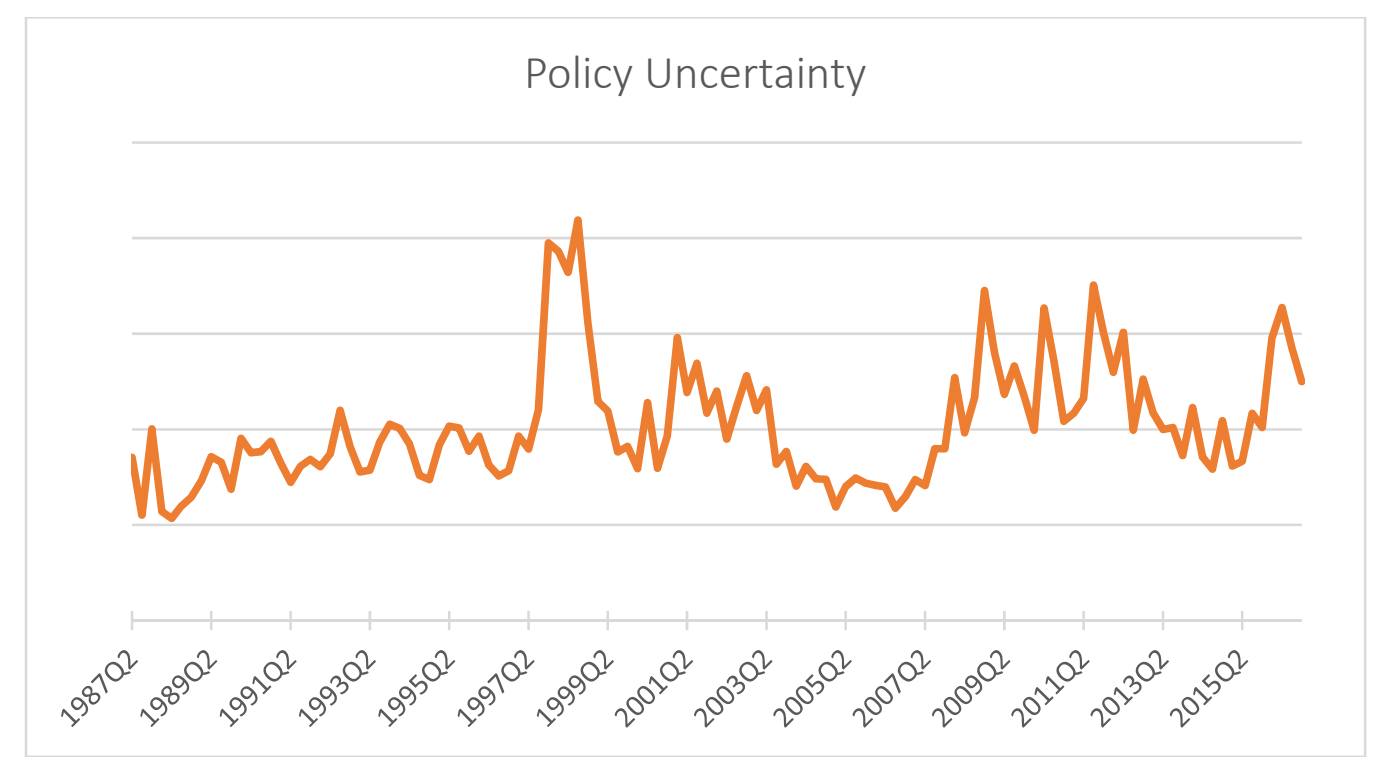

\footnotetext{
${ }^{2}$ See Economic Uncertainty Policy Group: http://www.policyuncertainty.com/europe monthly.html
} 
Review of Economic Analysis 12 (2020) 73-87

decrease in uncertainty? To answer these questions, we introduce the models and explain the methods in Section II. The results that mostly support the nonlinear specification of the demand for money in Japan and yields a positive answer to our asymmetry question are reported in Section III. Finally, while Section IV concludes, the data definition and sources are provided in an Appendix.

\section{The Models and Methods}

Following the literature, we begin with the following long-run specification of the demand for money in Japan:

$$
L n M_{t}=a+b \operatorname{Ln} Y_{t}+c \operatorname{Ln} R_{t}+d \operatorname{LnEX} X_{t}+e \operatorname{LnP} U_{t}+\varepsilon_{t}
$$

where $\mathrm{M}$ is the quantity of the money demanded. As can be seen, four variables are identified to be the long-run determinants of the demand for money. Real income $(\mathrm{Y})$ is included to account for the transaction property of money. Hence an estimate of $b$, which is expected to be positive, measures income elasticity. Its estimate basically guides policy makers to increase the money supply at the same rate that the economy grows. The interest rate, $\mathrm{R}$, measures the opportunity cost of holding cash against alternative assets, implying that an estimate of $\mathrm{c}$ is expected to be negative. The nominal effective exchange rate of yen, EX, is included to account for currency substitution. A yen depreciation or a decline in EX could have positive or negative effects on the demand for money. As the yen depreciates, the value of foreign assets held by the Japanese increases in yen. If this is perceived as an increase in wealth, the demand for money will increase. Hence a negative estimate for $d$ will support the wealth effect (Arango and Nadiri, 1981). However, as yen depreciates, Japanese could expect further depreciation and increase their holdings of foreign currencies by reducing their holdings of yen at home (Bahmani-Oskooee 1996). Thus, a positive estimate of $d$ will support the speculative effect of the exchange rate on the demand for money. ${ }^{3}$ Finally, we include the measure of policy uncertainty (PU) as our last determinant and as mentioned before, an estimate of e could be negative or positive.

As mentioned, since (1) is a long-run model, coefficients estimates measure long-run effects. To estimate the short-run effects, we follow Pesaran et al. (2001) and rewrite (1) in an error-correction modeling format as follows:

\footnotetext{
${ }^{3}$ We cannot forget to acknowledge and attribute the original idea of including the exchange rate in the money demand to Mundell (1963), though he did not engage in any empirical analysis.
} 
BAHMANI-OSKOOEE, NAYERI Policy Uncertainty and Demand for Money in Japan

$$
\begin{aligned}
\Delta L n M_{t}= & \alpha+\sum_{i=1}^{n 1} \beta_{i} \Delta \operatorname{Ln} M_{t-i}+\sum_{i=0}^{n 2} \delta_{i} \Delta \operatorname{Ln} Y_{t-i}+\sum_{i=0}^{n 3} \phi_{i} \Delta \operatorname{Ln} R_{t-i}+\sum_{i=0}^{n 4} \eta_{i} \Delta \operatorname{LnEX} X_{t-i} \\
& +\sum_{i=0}^{n 5} \lambda_{i} \Delta \operatorname{LnP} U_{t-i}+\rho_{0} \operatorname{Ln}_{t-1}+\rho_{1} \operatorname{Ln} Y_{t-1}+\rho_{2} \operatorname{Ln} R_{t-1}+ \\
& +\rho_{3} \operatorname{LnEX}_{t-1}+\rho_{4} \operatorname{LnP} U_{t-1}+\mu_{t}
\end{aligned}
$$

Note that in the above model, the linear combination of the lagged level variables are included as a proxy for lagged error term from (1). Pesaran et al. (2001) demonstrate that if this linear combination is jointly significant, that will support cointegration among all variables. The proposed test is the familiar F test with new critical values that they tabulate. Since the critical values account for integrating properties of variables, there is no need for unit root testing and indeed, variables could be integrated of order zero, I(0), or order one, I(1). This is the main advantage of this method. Once cointegration is established, long-run effects of all exogenous variables are derived by the estimates of $\rho_{1}-\rho_{4}$ normalized on $\rho_{0} .{ }^{4}$ As for the short-run effects of each variable, they are reflected in the estimates of coefficients attached to first-differenced variables.

Next we ask whether the rate at which Japanese decision to hold more or less cash is the same when policy uncertainty rises compared to when it falls. Let us assume due to $\mathrm{x} \%$ decrease in uncertainty, public decide to hold $\mathrm{y} \%$ less cash. When uncertainty rises by $\mathrm{x} \%$, the public may hold more than $\mathrm{y} \%$ cash in order to cover the uncertainty in the expected prolonged future. This implies that changes in policy uncertainty could have asymmetric effects on the demand for money. In order to investigate the asymmetric effects of policy uncertainty, we first form $\triangle L n P U$ which includes positive and negative changes. Then we use the partial sum concept to generate two new time-series variables as follows:

$$
\begin{aligned}
& P O S_{t}=\sum_{j=1}^{t} \Delta L n P U_{j}^{+}=\sum_{j=1}^{t} \max \left(\Delta \operatorname{LnP} U_{j}, 0\right), \\
& N E G_{t}=\sum_{j=1}^{t} \Delta L n P U_{j}^{-}=\sum_{j=1}^{t} \min \left(\Delta L n P U_{j}, 0\right)
\end{aligned}
$$

${ }^{4}$ By deduction then, $\hat{b}=\hat{\rho}_{1} /-\hat{\rho}_{0} ; \hat{c}=\hat{\rho}_{2} /-\hat{\rho}_{0} ; \hat{d}=\hat{\rho}_{3} /-\hat{\rho}_{0} ; \hat{e}=\hat{\rho}_{4} /-\hat{\rho}_{0}$. 
Where POS is the partial sum of positive changes and NEG is the partial sum of negative changes. The first variable reflects only increased uncertainty and the second one reflects decreased uncertainty. Shin et al. (2014) then recommend moving back to (2) and replacing LnPU by POS and NEG to arrive at:

$$
\begin{aligned}
& \Delta L n M_{t}=a^{\prime}+\sum_{i=1}^{n 1} b_{i}^{\prime} \Delta \operatorname{Ln} M_{t-i}+\sum_{i=0}^{n 2} c_{i}^{\prime} \Delta \operatorname{Ln} Y_{t-i}+\sum_{i=0}^{n 3} d_{i}^{\prime} \Delta \operatorname{Ln} R_{t-i}+\sum_{i=0}^{n 4} e_{i}^{\prime} \Delta \operatorname{LnEX} X_{t-i} \\
& +\sum_{i=0}^{n 5} g_{i}^{+} \Delta P O S_{t-i}+\sum_{i=0}^{n 6} g_{i}^{-} \Delta N E G_{t-i}+\lambda_{0} L n M_{t-1}+\lambda_{1} \operatorname{Ln} Y_{t-1} \\
& +\lambda_{2} \operatorname{LnR}_{t-1}+\lambda_{3} \operatorname{LnEX}_{t-1}+\lambda_{4}^{+} P O S_{t-1}+\lambda_{4}^{-} N E G_{t-1}+\psi_{t}
\end{aligned}
$$

Specification (4) is another error-correction model which Shin et al. (2014) call it the nonlinear ARDL model (NLARDL hereafter). They demonstrate that Pesaran et al.'s (2001) approach to estimate the linear model (2) is equally applicable to (4). ${ }^{5}$

Once (4) is estimated by using a lag selection criterion, several asymmetry assumptions could be tested. First, since critical values of the F test is higher for the linear model, Shin et al. (2014, p. 241) argue that we should use the same values for the nonlinear model even if the nonlinear model has one more variable. Second, if $n 5 \neq n 6$, i.e. $\Delta \mathrm{POS}$ takes a different lag order than $\triangle$ NEG, that will be an indication of adjustment asymmetry. Third, if at the same lag $\hat{g}_{i}^{+} \neq$ $\hat{g}_{i}^{-}$, that will support short-run asymmetric effects of policy uncertainty on the demand for money in Japan. However, if $\sum \hat{g}_{i}^{+} \neq \sum \hat{g}_{i}^{-}$, that will support short-run cumulative or impact asymmetric effects. This hypothesis will be tested by the Wald test. Finally, if the normalized coefficient attached to the POS variable is significantly different than the normalized coefficient attached to the NEG variable, i.e., if $\hat{\lambda}_{4}^{+} /_{-\hat{\lambda}_{0}} \neq \hat{\lambda}_{4}^{-} /_{-\hat{\lambda}_{0}}$, long-run asymmetric effects will be supported. Again, the Wald test will be used to confirm this inequality. ${ }^{6}$

\section{The Results}

In this section we estimate both the linear model (2) and the nonlinear model (4) using quarterly data from Japan over the period 1998 II -2016 II. The main reason for starting from 1998II is

\footnotetext{
${ }^{5}$ Note that the nonlinearity is introduced via the POS and NEG variables.

${ }^{6}$ For some other application of these methods in recent literature see Gogas and Pragidis (2015), Durmaz (2015), Baghestani and Kherfi (2015), Al-Shayeb and Hatemi-J.(2016), Lima et al. (2016), BahmaniOskooee and Mohammadian (2016), Bahmani-Oskooee and Fariditavana (2016), Aftab et al. (2017), Arize et al. (2017), and Gregoriou (2017).
} 
BAHMANI-OSKOOEE, NAYERI Policy Uncertainty and Demand for Money in Japan

the availability of the policy uncertainty measure which began in that year. A maximum of 12 lags is imposed on each first-differenced variable and Akaike's information criterion is used to select optimum models in each case. Furthermore, since a different test statistic is subject to a different critical value, we collect all critical values in the notes to each table and use them to identify significant estimates by * and **. If an estimate is significant at the $10 \%$ level, * is used. However, if an estimate is significant at the $5 \%$ level, ** are used.

As a preliminary exercise, we first provide summary statistics for each variable and ADF test results to make sure that we have no I(2) variable. These results are reported in Table1 and clearly show that there is no $\mathrm{I}(2)$ variable because all variables are stationary after being differenced once.

Next, we estimate the linear ARDL model and report the results in Table 2. From the shortrun estimates reported in Panel A, it is clear that only real income has short-run effects on the demand for money in Japan.

Table 1: Summary Statistics for All Variables

\begin{tabular}{|c|c|c|c|c|c|c|}
\hline & & \multicolumn{5}{|c|}{ Variables } \\
\hline & & $\mathrm{M}$ & $\mathrm{Y}$ & $\mathrm{R}$ & EX & PU \\
\hline \multirow{2}{*}{\multicolumn{2}{|c|}{ Mean }} & 6476292.7 & & & & \\
\hline & & 0 & 93.11706 & 1.529572 & 81.70443 & 101.2961 \\
\hline \multirow{2}{*}{\multicolumn{2}{|c|}{ Min }} & 3898555.1 & & & & \\
\hline & & 9 & 66.64 & 0.0104 & 56.6 & 53.42333 \\
\hline \multirow{2}{*}{\multicolumn{2}{|c|}{$\operatorname{Max}$}} & 9175272.9 & & & & \\
\hline & & 0 & 106.07 & 8.31 & 111.0567 & 209.4554 \\
\hline \multirow{2}{*}{\multicolumn{2}{|c|}{ Std Dev }} & 1377664.4 & & & & \\
\hline & & 7 & 9.275134 & 2.271164 & 12.15132 & 31.4767 \\
\hline \multicolumn{7}{|l|}{ Skewnes } \\
\hline $\mathrm{s}$ & & 0.186611 & -0.83898 & 1.582725 & 0.332352 & 1.222746 \\
\hline \multirow[t]{4}{*}{ Kurtosis } & & 1.952815 & 3.153233 & 4.31064 & 2.760731 & 4.402552 \\
\hline & \multicolumn{6}{|c|}{ Augmented Dickey-Fuller test } \\
\hline & & & \multicolumn{4}{|c|}{ Variables } \\
\hline & & Ln M & Ln Y & Ln R & Ln EX & Ln PU \\
\hline \multirow{2}{*}{$\begin{array}{l}\text { With } \\
\text { Constant }\end{array}$} & Level & $-1.30(1)$ & $-4.17(0)^{* *}$ & $-0.77(0)$ & $-2.52(3)$ & $-4.22(0)^{* *}$ \\
\hline & $\begin{array}{l}\text { First } \\
\text { Difference }\end{array}$ & $-5.88(0)^{* *}$ & $-9.97(0)^{* *}$ & $\begin{array}{c}- \\
8.82(1)^{* *}\end{array}$ & $-4.81(2)^{* *}$ & $-15.26(0)^{* *}$ \\
\hline \multirow{2}{*}{$\begin{array}{l}\text { With } \\
\text { Constant } \\
\text { and } \\
\text { Trend }\end{array}$} & Level & $-3.95(1)^{* *}$ & $-4.39(0)^{* *}$ & $-1.84(0)$ & $-3.02(3)$ & $-4.60(0)^{* *}$ \\
\hline & $\begin{array}{l}\text { First } \\
\text { Difference }\end{array}$ & $-5.93(0)^{* *}$ & $\begin{array}{c}- \\
10.39(0)^{* *}\end{array}$ & $\begin{array}{c}- \\
8.80(1)^{* *}\end{array}$ & $-4.79(2)^{* *}$ & $-15.20(0)^{* *}$ \\
\hline
\end{tabular}

Notes: Real money supply (M) IS in Millions of Japanese Yen.

Std Dev is standard deviation. * and ** denote statistical significance at the $10 \%$ and $5 \%$ confidence levels, respectively. Number inside the parenthesis is the number of lags selected by AIC. 
Review of Economic Analysis 12 (2020) 73-87

Table 2: Full-information estimates of Both Linear and Nonlinear Models

\begin{tabular}{|c|c|c|c|c|c|c|}
\hline \multicolumn{7}{|c|}{ I. Linear ARDL Model } \\
\hline \multicolumn{7}{|c|}{ Panel A: short-run coefficient estimates } \\
\hline Lag order & 0 & 1 & 2 & 3 & 4 & 5 \\
\hline$\Delta \mathrm{LnM}$ & & $\begin{array}{c}0.39 \\
(4.43)^{* *}\end{array}$ & & & & \\
\hline$\Delta \mathrm{LnY}$ & $\begin{array}{c}-0.068 \\
(-3.17)^{* *}\end{array}$ & & & & & \\
\hline$\Delta \mathrm{LnR}$ & $\begin{array}{l}-0.001 \\
(-1.40)\end{array}$ & & & & & \\
\hline$\triangle \mathrm{LnLEX}$ & $\begin{array}{l}0.001 \\
(0.17)\end{array}$ & & & & & \\
\hline$\Delta \mathrm{LnPU}$ & $\begin{array}{l}0.003 \\
(1.47)\end{array}$ & & & & & \\
\hline
\end{tabular}

Panel B: long-run coefficient estimates

\begin{tabular}{c|c|c|c|c|c}
\hline Constant & LnY & LnR & LnEX & LnPU & \\
\hline 12.07 & 4.03 & 0.044 & -0.049 & -0.19 & \\
$(2.42)^{* *}$ & $(3.32)^{* *}$ & $(1.08)$ & $(-0.16)$ & $(-1.14)$ & \\
\hline \multicolumn{7}{c}{ Panel C: Diagnostics } \\
\hline F & ECM $_{\mathrm{t}-1}$ & LM & RESET & $\bar{R}^{2}$ & CUSUM (CUSUMQ) \\
\hline 2.60 & 0.017 & 1.13 & $4.96^{* *}$ & 0.35 & Unstable \\
& $(1.90)$ & & & & \\
\hline
\end{tabular}

Notes:

a. Numbers inside the parentheses are t-ratios. *, ** indicate significance at the $10 \%$ and $5 \%$ levels respectively.

b. The upper bound critical value of the F-test for cointegration when there are four exogenous variables is 3.52 (4.01) at the 10\% (5\%) level of significance. These come from Pesaran et al. (2001, Table CI, Case III, p. 300).

c. The critical value for significance of $\mathrm{ECM}_{\mathrm{t}-1}$ is $-3.66(-3.99)$ at the $10 \%(5 \%)$ level when $\mathrm{k}=4$. The comparable figures when $\mathrm{k}=5$ in the nonlinear model are -3.86 and -4.19 respectively. These come from Pesaran et al. (2001, Table CII, Case III, p. 303).

d. LM is the Lagrange Multiplier statistic to test for autocorrelation. It is distributed as $\chi^{2}$ with 1 degree of freedom. The critical value is $2.70(3.84)$ at the $10 \%(5 \%)$ significance level.

e. RESET is Ramsey's test for misspecification. It is distributed as $\chi^{2}$ with one degree of freedom. The critical value is $2.70(3.84)$ at the $10 \%(5 \%)$ significance level.

The same is true when we shift to long-run estimates in Panel B. However, the long-run link between cash holding and real income seems to be spurious since neither the $\mathrm{F}$ test nor the $\mathrm{ECM}_{\mathrm{t}-1}$ test reported in Panel $\mathrm{C}$ are significant. ${ }^{7}$ We have also reported the Lagrange multiplier

${ }^{7}$ The ECM $\mathrm{EC}_{\mathrm{t}-1}$ test is an alternative test under which we use long-run normalized coefficients and long-run
specification (1) to generate the error term. Denoting this error term by ECM, we then replace the 
(LM) test for first order autocorrelation and as can be seen, it is insignificant, implying a lack of serial correlation. Ramey's reset test, however, is significant, supporting a misspecified model. We have also applied the well-known CUSUM and CUSUMSQ tests to the residuals and have indicated that estimates are unstable. How do the results change if we consider estimates of the nonlinear model?

Coefficient estimates and diagnostics of the nonlinear model are reported in Table 3. From the short-run estimates, it is clear that all variables except $\triangle \mathrm{POS}$ have short-run effects on the demand for money in Japan. The fact that yen appreciation, $\triangle \mathrm{POS}$, has no short-run effects but yen depreciation, $\triangle \mathrm{NEG}$, does have short-run effects, supports asymmetric effects of policy uncertainty in the short run. However, stronger support for short-run cumulative or impact asymmetric effects is provided by the significant Wald test, reported as Wald-S in Panel C of Table 3. As mentioned before, the significant Wald-S statistic implies that the sum of the coefficients attached to $\triangle \mathrm{POS}$ variables is different than the sum attached to the $\triangle \mathrm{NEG}$ variable. Do short-run effects translate into the long run?

Long-run normalized estimates reported in Panel B of Table 3 reveal that all variables carry significant coefficients except the exchange rate. Income elasticity is significantly positive and interest rate elasticity is significantly negative, in line with our expectation. ${ }^{8}$ It appears that changes in policy uncertainty in Japan also has long-run asymmetric effects on the demand for money. Both increase uncertainty and decreased uncertainty increases Japanese cash holdings. Increased uncertainty induces people to hold more cash against an uncertain future and so does decreased uncertainty. This could be due to the fact that Japanese will find themselves always worried about the future and try to hedge against an uncertain future by holding more cash. These long-run asymmetric effects is further supported by a significant Wald statistic reported as Wald-L in Panel C. Furthermore, all long-run estimates are meaningful since cointegration is supported by the $\mathrm{F}$ or $\mathrm{ECM}_{\mathrm{t}-1}$ test. Additionally, residuals are autocorrelation free since the LM test is insignificant and there is no evidence of misspecification since the RESET test is insignificant. Finally, all estimates are stable, as reflected by the application of CUSUM and CUSUMSQ tests and reported in Figure 2. ${ }^{9}$

As an additional exercise, we thought to change the threshold level of constructing partial sum variables from zero to $2 \%$ as in (5) below and carry out the entire analysis one more time.

lagged level variables in (2) by $\mathrm{ECM}_{\mathrm{t}-1}$ and estimate this new specification after imposing the same optimum lag orders. If $\mathrm{ECM}_{\mathrm{t}-1}$ carries a significantly negative coefficient, cointegration is supported. Since the t-test is used to judge the significance of the estimated coefficient, the test is also known as the t-test for which Pesaran et al. (2001, p. 303) tabulated new critical values.

${ }^{8}$ Note that although interest rate elasticity is significant, its size is very small and this is consistent with the so called "Zero Interest Rate Policy" in Japan that was introduced in February 1999.

${ }^{9}$ Note that in the nonlinear model, the long-run demand for money is specified as:

$L n M_{t}=a+b \operatorname{Ln} Y_{t}+c \operatorname{Ln} R_{t}+d \operatorname{LnEX} X_{t}+e P O S_{t}+f N E G_{t}+\varepsilon_{t}$. 
Review of Economic Analysis 12 (2020) 73-87

Table 3: Full Information Estimate of the Nonlinear ARDL Model

\begin{tabular}{|c|c|c|c|c|c|c|c|c|c|c|c|}
\hline \multicolumn{12}{|c|}{ Panel A: short-run coefficient estimates } \\
\hline Lag order & 0 & 1 & 2 & 3 & 4 & 5 & 6 & 7 & 8 & 9 & 10 \\
\hline$\Delta \mathrm{LnM}$ & - & $\begin{array}{c}0.16 \\
(1.38)\end{array}$ & $\begin{array}{c}0.25 \\
(2.46)^{* *}\end{array}$ & $\begin{array}{c}0.19 \\
(2.12)^{*}\end{array}$ & $\begin{array}{c}0.07 \\
(0.70)\end{array}$ & $\begin{array}{c}0.25 \\
(2.99)^{* *}\end{array}$ & $\begin{array}{c}0.31 \\
(4.12)^{* *}\end{array}$ & $\begin{array}{c}0.08 \\
(0.86)\end{array}$ & $\begin{array}{c}0.02 \\
(0.24)\end{array}$ & $\begin{array}{c}0.16 \\
(1.52)\end{array}$ & $\begin{array}{c}0.24 \\
(2.88)^{* *}\end{array}$ \\
\hline$\Delta \mathrm{LnY}$ & $\begin{array}{c}0.14 \\
(1.57)\end{array}$ & $\begin{array}{c}0.11 \\
(1.18)\end{array}$ & $\begin{array}{c}-0.05 \\
(-0.76)\end{array}$ & $\begin{array}{c}-0.09 \\
(-2.09)^{*}\end{array}$ & & & & & & & \\
\hline$\Delta \mathrm{LnR}$ & $\begin{array}{l}0.0004 \\
(0.41)\end{array}$ & $\begin{array}{l}0.001 \\
(0.56)\end{array}$ & $\begin{array}{c}0.0003 \\
(0.19)\end{array}$ & $\begin{array}{c}-0.004 \\
(-2.78)^{* *}\end{array}$ & $\begin{array}{c}0.01 \\
(3.31)^{* *}\end{array}$ & $\begin{array}{l}-0.003 \\
(-1.47)\end{array}$ & $\begin{array}{c}-0.0001 \\
(-0.03)\end{array}$ & $\begin{array}{l}0.003 \\
(1.67)\end{array}$ & $\begin{array}{l}0.0005 \\
(0.24)\end{array}$ & $\begin{array}{l}-0.003 \\
(-1.42)\end{array}$ & $\begin{array}{l}0.002 \\
(1.49)\end{array}$ \\
\hline$\Delta$ LnLEX & $\begin{array}{l}0.002 \\
(0.17)\end{array}$ & $\begin{array}{c}0.01 \\
(0.38)\end{array}$ & $\begin{array}{c}0.03 \\
(1.66)\end{array}$ & $\begin{array}{c}-0.05 \\
(-3.20)^{* *}\end{array}$ & $\begin{array}{c}0.01 \\
(0.69)\end{array}$ & $\begin{array}{c}-0.03 \\
(- \\
2.44)^{* *}\end{array}$ & $\begin{array}{c}0.05 \\
(4.55)^{* *}\end{array}$ & & & & \\
\hline$\triangle \mathrm{POS}$ & $\begin{array}{l}-0.001 \\
(-0.20)\end{array}$ & $\begin{array}{c}-0.01 \\
(-0.67)\end{array}$ & $\begin{array}{l}-0.01 \\
(-1.96)\end{array}$ & $\begin{array}{c}0.01 \\
(1.40)\end{array}$ & $\begin{array}{l}0.002 \\
(0.22)\end{array}$ & $\begin{array}{c}-0.01 \\
(-1.52)\end{array}$ & $\begin{array}{c}0.01 \\
(1.33)\end{array}$ & $\begin{array}{l}-0.003 \\
(-0.43)\end{array}$ & $\begin{array}{c}-0.0002 \\
(-0.02)\end{array}$ & $\begin{array}{l}0.001 \\
(0.19)\end{array}$ & $\begin{array}{c}0.02 \\
(3.79)\end{array}$ \\
\hline$\triangle \mathrm{NEG}$ & $\begin{array}{c}0.01 \\
(0.60) \\
\end{array}$ & $\begin{array}{c}0.02 \\
(2.27)^{*}\end{array}$ & $\begin{array}{c}0.01 \\
(1.53) \\
\end{array}$ & $\begin{array}{c}-0.03 \\
(-3.00) * *\end{array}$ & $\begin{array}{l}-0.004 \\
(-0.49)\end{array}$ & $\begin{array}{c}0.03 \\
(4.29)^{* *} \\
\end{array}$ & $\begin{array}{c}-0.01 \\
(-0.91) \\
\end{array}$ & $\begin{array}{c}-0.01 \\
(-1.28) \\
\end{array}$ & & & \\
\hline
\end{tabular}

Panel B: long-run coefficient estimates

\begin{tabular}{|c|c|c|c|c|c|c|c|}
\hline Constant & LnY & LnR & LnEX & POS & NEG & & \\
\hline $\begin{array}{c}27.91 \\
(95.01)^{* *}\end{array}$ & $\begin{array}{c}0.28 \\
(4.17)^{* *}\end{array}$ & $\begin{array}{c}-0.005 \\
(- \\
3.82)^{* *}\end{array}$ & $\begin{array}{l}-0.01 \\
(-0.61)\end{array}$ & $\begin{array}{c}0.02 \\
(2.05)^{*}\end{array}$ & $\begin{array}{c}-0.05 \\
(-6.16)^{* *}\end{array}$ & & \\
\hline \multicolumn{8}{|c|}{ Panel C: Diagnostics } \\
\hline $\mathrm{F}$ & $\mathrm{ECM}_{\mathrm{t}-1}$ & LM & RESET & $\bar{R}^{2}$ & CUSUM (CUSUMQ) & Wald-L & Wald-S \\
\hline $11.03 * *$ & $\begin{array}{c}-0.55 * * \\
(-8.06)\end{array}$ & 2.47 & 0.42 & 0.62 & Stable & $1796.71 * *$ & $8.40 * *$ \\
\hline
\end{tabular}

Notes:

a. Numbers inside the parentheses are absolute value of t-ratios. * ** indicate significance at the $10 \%$ and $5 \%$ levels respectively.

b. The upper bound critical value of the F-test for cointegration when there are four exogenous variables is 3.52 (4.01) at the $10 \%(5 \%)$ level of significance. These come from Pesaran et al. (2001, Table CI, Case III, p. 300).

c. The critical value for significance of ECMt-1 is $-3.66(-3.99)$ at the $10 \%(5 \%)$ level when $\mathrm{k}=4$. The comparable figures when $\mathrm{k}=5$ in the nonlinear model are -3.86 and -4.19 respectively. These come from Pesaran et al. (2001, Table CII, Case III, p. 303).

d. LM is the Lagrange Multiplier statistic to test for autocorrelation. It is distributed as $\chi^{2}$ with 1 degree of freedom. The critical value is $2.70(3.84)$ at the $10 \%(5 \%)$ significance level.

e. RESET is Ramsey's test for misspecification. It is distributed as $\chi 2$ with one degree of freedom. The critical value is $2.70(3.84)$ at the $10 \%(5 \%)$ significance level.

f. Both Wald tests are also distributed as $\chi^{2}$ with one degree of freedom. The critical value is 2.70 (3.84) at the $10 \%(5 \%)$ significance level. 
BAHMANI-OSKOOEE, NAYERI Policy Uncertainty and Demand for Money in Japan

$$
\begin{aligned}
& P O S_{t}=\sum_{j=1}^{t} \Delta L n P U_{j}^{+}=\sum_{j=1}^{t} \max \left(\Delta \operatorname{LnP} U_{j}, 0.02\right), \\
& N E G_{t}=\sum_{j=1}^{t} \Delta L n P U_{j}^{-}=\sum_{j=1}^{t} \min \left(\Delta \operatorname{LnP} U_{j}, 0.02\right)
\end{aligned}
$$

The results are reported in Table 4 and as can be seen, there is no change in our previous conclusion that in Japan economic policy uncertainty has asymmetric effects on the demand for money.

\begin{tabular}{|c|c|c|c|c|c|c|c|c|c|c|c|}
\hline Lag order & 0 & 1 & 2 & 3 & 4 & 5 & 6 & 7 & 8 & 9 & 10 \\
\hline \multirow[t]{2}{*}{$\Delta \mathrm{LnM}$} & 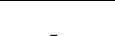 & 0.16 & 0.21 & 0.24 & 0.01 & 0.28 & 0.31 & 0.08 & 0.07 & 0.09 & 0.34 \\
\hline & - & (1.41) & (1.79) & $(2.12)^{*}$ & $(0.07)$ & $(2.83)^{* *}$ & $(4.01)^{* *}$ & $(0.73)$ & $(0.68)$ & $(0.76)$ & $(3.62)^{* *}$ \\
\hline \multirow[t]{2}{*}{$\Delta \mathrm{LnY}$} & 0.12 & 0.10 & -0.05 & -0.13 & 0.13 & -0.10 & 0.04 & -0.08 & 0.10 & -0.05 & \\
\hline & $(1.25)$ & $(1.33)$ & $(-0.77)$ & $(-1.42)$ & (1.13) & $(-1.35)$ & $(0.56)$ & $(-1.34)$ & $(2.08)^{*}$ & $(-1.18)$ & \\
\hline \multirow[t]{2}{*}{$\Delta \mathrm{LnR}$} & -0.001 & 0.002 & 0.0004 & -0.01 & 0.01 & -0.004 & 0.002 & 0.002 & 0.002 & -0.004 & 0.003 \\
\hline & $(-0.64)$ & (1.14) & $(0.23)$ & $(-2.81)^{* *}$ & $(3.21)^{* *}$ & $(-2.15)^{*}$ & $(0.92)$ & $(1.06)$ & $(0.87)$ & $(-1.86)$ & $(2.18)^{*}$ \\
\hline$\Delta$ LnLEX & $\begin{array}{c}0.0003 \\
(0.04)\end{array}$ & $\begin{array}{c}0.01 \\
(0.71)\end{array}$ & $\begin{array}{c}0.03 \\
(1.48)\end{array}$ & $\begin{array}{c}-0.05 \\
(-3.08)^{* *}\end{array}$ & $\begin{array}{c}0.02 \\
(0.85)\end{array}$ & $\begin{array}{c}-0.03 \\
(-2.17)^{*}\end{array}$ & $\begin{array}{c}0.04 \\
(4.06)^{* *}\end{array}$ & & & & \\
\hline$\triangle \mathrm{POS}$ & $\begin{array}{l}-0.01 \\
(-0.84)\end{array}$ & $\begin{array}{l}0.001 \\
(0.14)\end{array}$ & $\begin{array}{c}-0.02 \\
(-2.63)^{* *}\end{array}$ & $\begin{array}{c}0.02 \\
(1.92)\end{array}$ & $\begin{array}{l}-0.003 \\
(-0.46)\end{array}$ & $\begin{array}{l}-0.01 \\
(-0.98)\end{array}$ & $\begin{array}{c}0.01 \\
(0.81)\end{array}$ & $\begin{array}{l}0.003 \\
(0.41)\end{array}$ & $\begin{array}{c}-0.0004 \\
(-0.06)\end{array}$ & $\begin{array}{l}-0.002 \\
(-0.32)\end{array}$ & $\begin{array}{c}0.02 \\
(2.64)^{* *}\end{array}$ \\
\hline$\triangle \mathrm{NEG}$ & $\begin{array}{c}0.01 \\
(0.96)\end{array}$ & $\begin{array}{c}0.01 \\
(1.33)\end{array}$ & $\begin{array}{c}0.02 \\
(2.17)^{*}\end{array}$ & $\begin{array}{c}-0.03 \\
(-2.54)^{* *}\end{array}$ & $\begin{array}{l}-0.003 \\
(-0.39)\end{array}$ & $\begin{array}{c}0.03 \\
(3.84)^{* *}\end{array}$ & $\begin{array}{l}-0.005 \\
(-0.60)\end{array}$ & $\begin{array}{c}-0.01 \\
(-1.41)\end{array}$ & & & \\
\hline \multicolumn{12}{|c|}{ Panel B: long-run coefficient estimates } \\
\hline Constant & LnY & LnR & LnEX & POS & NEG & & & & & & \\
\hline 27.91 & 0.27 & -0.01 & 0.001 & 0.02 & -0.05 & & & & & & \\
\hline$(85.45)^{* *}$ & $(3.68) * *$ & $(-4.35)^{* *}$ & $(0.11)$ & $(2.71)^{* *}$ & $(-6.87)^{* *}$ & & & & & & \\
\hline \multicolumn{12}{|c|}{ Panel C: Diagnostics } \\
\hline $\mathrm{F}$ & $\mathrm{ECM}_{\mathrm{t}-1}$ & LM & RESET & $\bar{R}^{2}$ & \multicolumn{2}{|c|}{ CUSUM (CUSUMQ) } & \multicolumn{2}{|c|}{ Wald-L } & \multicolumn{2}{|c|}{ Wald-S } & \\
\hline $10.25^{*}$ & $\begin{array}{c}-0.57 * * \\
(-7.78)\end{array}$ & 0.57 & 0.44 & 0.62 & \multicolumn{2}{|c|}{ Stable } & \multicolumn{2}{|c|}{$1291.31 * *$} & \multicolumn{2}{|c|}{$5.65 * *$} & \\
\hline
\end{tabular}

Table 4 Full-information estimates of Nonlinear Model with 2\% Thresholds

Notes:

a. Numbers inside the parentheses are absolute value of t-ratios. $* * *$ indicate significance at the $10 \%$ and $5 \%$ levels respectively.

b. The upper bound critical value of the F-test for cointegration when there are four exogenous variables is 3.52 (4.01) at the $10 \%(5 \%)$ level of significance. These come from Pesaran et al.(2001, Table CI, Case III, p. 300).

c. The critical value for significance of $\mathrm{ECM}_{\mathrm{t}-1}$ is $-3.66(-3.99)$ at the $10 \%(5 \%)$ level when $\mathrm{k}=4$. The comparable figures when $\mathrm{k}=5$ in the nonlinear model are -3.86 and -4.19 respectively. These come from Pesaran et al. (2001, Table CII, Case III, p. 303).

d. LM is the Lagrange Multiplier statistic to test for autocorrelation. It is distributed as $\chi^{2}$ with 1 degree of freedom. The critical value is $2.70(3.84)$ at the $10 \%(5 \%)$ significance level.

e. RESET is Ramsey's test for misspecification. It is distributed as $\chi^{2}$ with one degree of freedom. The critical value is $2.70(3.84)$ at the $10 \%(5 \%)$ significance level.

f. Both Wald tests are also distributed as $\chi^{2}$ with one degree of freedom. The critical value is $2.70(3.84)$ at the $10 \%(5 \%)$ significance level. 
Review of Economic Analysis 12 (2020) 73-87

\section{Concluding Remarks}

In the early 1980s when the Fed missed its inflation target, Friedman (1984) blamed the volatility of the money supply, which was said to contribute to an unstable velocity or unstable demand for money. Subsequently, another study demonstrated that if money supply volatility can affect the demand for money and its stability, so can output volatility. This has led to a body of the literature which includes monetary and output volatility as two measures of uncertainty in the specification and estimation of the money demand. Indeed, some have shown that once the two measures are included in the money demand, it becomes stable. Intuitively, increased uncertainty could induce people to hold more cash today in order to cover themselves in the future. However, if they perceive any uncertainty to result in an inflationary environment, they may hold less cash and more real assets to hedge against future inflation.

While previous research has addressed the above issue using data from several countries, no study has considered the experience of Japan. In this paper, we consider the experience of Japan but rather than including money supply and output volatility as uncertainty measures, we include a relatively more comprehensive measure of uncertainty known as economic policy uncertainty. This new measure is constructed by including many factors that contribute to an uncertain environment. These factors could be political, economical, social, etc. Such a measure is constructed and published by Economic Policy Uncertainty Group using the method in Bakers et al. (2016).

When we included the measure of economic policy uncertainty in the demand for money in Japan, we were unable to find a stable money demand and meaningful estimates. Suspecting that economic policy uncertainty could adjust nonlinearly, we introduced its nonlinear adjustment into our specification through partial sum approach and not just found a stable money demand in Japan, but also meaningful estimates. Since the nonlinear approach also allows us to determine whether economic policy uncertainty changes have symmetric or asymmetric effects on the Japanese demand for money, we were able to confirm short-run as well as long-run asymmetric effects. In sum, we found that in Japan, the public hold more cash when there is either an increase or a decrease in uncertainty.

\section{APPENDIX}

\section{Data Definition and Sources}

Quarterly data over the period 1998 II -2016 II are used to carry out the estimation. The main restriction for using data prior to 1998 is unavailability of data on policy uncertainty. Data are collected from the following sources:

(a) International Financial Statistics (IFS) of International Monetary Fund (IMF).

(b) Economic Policy Uncertainty Group:

http:// www.policyuncertainty.com/europe monthly.html 
BAHMANI-OSKOOEE, NAYERI Policy Uncertainty and Demand for Money in Japan

\section{Variables:}

M3 = Money supply measured by real M3. Nominal M3 figures are deflated by GDP deflator. Data come from Source (a).

$Y=$ Nominal GDP is deflated by GDP deflator to arrive at real GDP $(2010=100)$. Data come from Source (a).

$R=$ Interest rate. Money market rates come from Source (a).

$E X=$ Index of nominal effective exchange rate of the Japanese yen. A decline reflects a depreciation of yen. Data come from Source (a).

$P U=$ policy uncertainty measure. Data come from Source (b).

\section{References}

Aftab, M., K. Shah Syed, N. A. Katper, (2017) Exchange-rate volatility and Malaysian-Thai bilateral industry trade flows, Journal of Economic Studies, 44, 99-114.

Al-Shayeb, A. and A.Hatemi-J., (2016) Trade openness and economic development in the UAE: an asymmetric approach, Journal of Economic Studies,43, 587-597.

Arango, Sebastian, and M. Ishag Nadiri (1981), Demand for Money in Open economies, Journal of Monetary Economics, 7 69-83.

Arize, A. C., J. Malindretos, and E.U. Igwe, (2017), Do Exchange Rate Changes Improve the Trade Balance: An Asymmetric Nonlinear Cointegration Approach, International Review of Economics and Finance,49,313-326.

Baghestani, H. and S. Kherfi, (2015) An error-correction modeling of US consumer spending: are there asymmetries?, Journal of Economic Studies,42, 1078-1094.

Bahmani-Oskooee, M. (1996), The Black Market Exchange Rate and Demand for Money in Iran Journal of Macroeconomics, 18,171-176.

Bahmani-Oskooee, M. (2001), How Stable is M2 Money Demand Function in Japan?, Japan and the World Economy,13,455-461.

Bahmani-Oskooee, Mohsen and Mohammad Pourheydarian (1990), Exchange Rate Sensitivity of the Demand for Money and Effectiveness of Fiscal and Monetary Policies, Applied Economics, 22, 1377-1384.

Bahmani-Oskooee, M. and G. Shabsigh (1996), The Demand for Money in Japan: Evidence from Cointegration Analysis, Japan and the World Economy,8,1-10.

Bahmani-Oskooee, M. and Dan Xi, (2011), Economic Uncertainty, Monetary Uncertainty and the Demand for Money in Australia, Australian Economic Papers,50115-128. 
Bahmani-Oskooee, M. and D. Xi (2014), Economic Uncertainty, Monetary Uncertainty, and the Demand for Money: Evidence from Asian Countries. Australian Economic Papers,53, 16-28.

Bahmani-Oskooee, M. and A. Mohammadain (2016), Asymmetry Effects of Exchange Rate Changes on Domestic Production: Evidence from Nonlinear ARDL Approach, Australian Economic Papers,55,181-191.

Bahmani-Oskooee, M. and H. Fariditavana (2016), Nonlinear ARDL Approach and the J-Curve Phenomenon, Open Economies Review, 27,51-70.

Bahmani-Oskooee, M. and J. Baek (2017), Economic Uncertainty, Monetary Uncertainty and the Korean Demand for Money, Journal of Economic Policy Reform,20,86-97.

Bahmani-Oskooee, M., A. Kutan, and D. Xi, (2013), The Impact of Economic and Monetary Uncertainty on the Demand for Money in Emerging Economies, Applied Economics, 45,3278-3287.

Baker, S.R., N. Bloom, and S.J. Davis, (2016), Measuring Economic Policy Uncertainty, Quarterly Journal of Economics,131,1593-1636.

Bruggemann, I. and D. Nautz (1997), Money Growth Volatility and the Demand for Money in Germany: Friedman's Volatility Hypothesis Revisited, Weltwirtschaftliches Archiv, 133,523-537.

Choi, Woon Gyu and Seonghwan Oh (2003), A Money Demand Function with Output Uncertainty, Monetary Uncertainty, and Financial Innovation, Journal of Money, Credit, and Banking,35,685-709.

Durmaz, Nazif (2015), Industry Level J-Curve in Turkey, Journal of Economic Studies,42,689706.

Fair, Ray C. (1987), International Evidence on the Demand for Money, The Review of Economics and Statistics, 69,473-480.

Friedman, M. (1984), Lessons from the 1979-1982 Monetary Policy Experiment, American Economic Review, Papers and Proceedings, 74,397-400.

Gogas, P. and I. Pragidis, (2015) Are there asymmetries in fiscal policy shocks?, Journal of Economic Studies,42, 303-321.

Gregoriou, A. (2017) Modelling non-linear behavior of block price deviations when trades are executed outside the bid-ask quotes., Journal of Economic Studies,44,206-213.

Hall, T. and N. Noble, (1987), Velocity and Variability of Money Growth: Evidence from Granger-Causality Tests, Journal of Money, Credit, and Banking,19,112-116.

Hoffman, D. L., R.H. Rasche, and M.A. Tieslau (1995), The Stability of Long-Run Money Demand in Five Industrial Countries, Journal of Monetary Economics,35,317-339.

Lima, L., C. Foffano Vasconcelos, J. Simão, and H. de Mendonça, (2016) The quantitative easing effect on the stock market of the USA, the UK and Japan: An ARDL approach for the crisis period, Journal of Economic Studies,43, 1006-1021. 
BAHMANI-OSKOOEE, NAYERI Policy Uncertainty and Demand for Money in Japan

Miyao, R., (1996), Does a Cointegrating M2 Demand Relation Really Exist in Japan?, Journal of the Japanese and International Economies, 10,169-180.

Mundell, A. Robert, Capital Mobility and Stabilization Policy under Fixed and Flexible Exchange Rates (1963), Canadian Journal of Economics and Political Science,29, 475-485.

Pesaran, M. H., Y. Shin, and R. J. Smith., Bounds Testing Approaches to the Analysis of Level Relationships, Journal of Applied Econometrics. 16 (2001), 289 -326.

Shin, Y, B. C. Yu, and M. Greenwood-Nimmo (2014) Modelling Asymmetric Cointegration and Dynamic Multipliers in a Nonlinear ARDL Framework Festschrift in Honor of Peter Schmidt: Econometric Methods and Applications, eds. by R. Sickels and W. Horrace: Springer, 281-314.

Valadkhani, Abbas (2005), Modelling Demand for Broad Money in Australia, Australian Economic Papers,44,47-64. 